\title{
REGULATION AND DEREGULATION OF THE NATURAL GAS INDUSTRY IN THE UNITED STATES
}

\author{
ARNOLD R. MADIGAN*, DEBORAH A. MACDONALD, DARI R. DORNAN AND \\ HENRY C. ROSENTHAL, JR.**
}

\begin{abstract}
This paper deals with the effects of natural gas industry regulation and deregulation in the United States on the marketing of Canadian gas.
\end{abstract}

\section{INTRODUCTION}

At this writing there are strong currents of change in U.S. regulation and deregulation of natural gas which will shape the course of the industry both in the near term and in the years to come. In the federal government, these changes are taking place at the administrative agency level, although there may also be some prospect for limited legislative change. Changes are also occurring at the state level. A new regulatory and marketing infrastructure is evolving in response to these changes. The marketing of Canadian gas in the United States and Canada will be affected by those changes, as will the marketing of U.S. gas supplies.

\section{OPEN ACCESS TO TRANSPORTATION}

On October 9, 1985, the Federal Energy Regulatory Commission (FERC) in Order No. 436 issued a Final Rule in Docket No. RM85-1-000 (Parts A-D).' 'Order No. 436 was the final result of a Notice of Proposed Rulemaking (NOPR) issued by the FERC on May 30, 1985, in Docket No. RM85-1-000, ${ }^{2}$ which proposed changes to the regulation of natural gas pipelines after partial wellhead decontrol of gas on January 1, 1985.

\section{A. PRINCIPAL FEATURES OF ORDER NO. 436 TRANSPORTATION PROGRAM}

Order No. 436, Part A, establishes a "voluntary" self-implementing transportation program which replaces the FERC's former self-implementing transportation programs under Order Nos. 234, 234-B, 319, 319$A, 60,63$, and Part 284 of the Commission's regulations.

Interstate pipelines who elect to participate under the program must offer transportation services to all shippers on a non-discriminatory basis. Non-discriminatory access to self-implementing transportation services under section 7 of the Natural Gas Act (NGA) and section 311 of the Natural Gas Policy Act (NGPA) is the "comerstone" of the Commission's final rule.

- Vice President and General Counsel, Northern Natural Gas Company, Division of Enron Corp.; member of the Bars of Nebraska, Minnesota and Colorado.

-* Attorneys, Northern Natural Gas Company, Division of Enron Corp.; members of the Bar of Nebraska.

1. Order No. 436, Regulation of Natural Gas Pipelines After Partial Wellhead Decontrol, Docket No. RM85-1-000 (Parts A-D), s0 Fed. Reg. 42,408 (October 18, 1985), FERC Statutes and Regulations 930,665 . Technical corrections issued October 24, 1985, 50 Fed. Reg. 45,907 (November 5, 1985), FERC Statutes and Regulations 930,669.

2. Regulation of Natural Gas Pipelines After Partial Wellhead Decontrol, Docket No. RM85-1000 (Parts A-D), 50 Fed. Reg. 24,130 (June 7, 1985). 
Participating interstate pipelines must offer transportation services on both a firm and interruptible basis, subject to the availability of capacity. Available capacity must be allocated on a first come, first served basis, without preference as between firm sales and firm transportation customers or between interruptible sales and interruptible transportation.

Transportation services for shippers who qualify under section 311 of the NGPA (intrastate and "Hinshaw" pipelines and local distribution companies or LDC's) may be performed under Order No. 436 on a selfimplementing basis. A participating pipeline is required to apply for and receive a blanket transportation certificate under Order No. 436 and section 7(c) of the NGA in order to commence new transportation arrangements for other than section 311 shippers. Upon receipt of a blanket transportation certificate, an interstate pipeline may transport for other interstate pipelines on a self-implementing basis on the same terms and conditions as it may transport for a qualified section 311 shipper. An interstate pipeline may transport for all other shippers pursuant to its blanket certificate authority on a self-implementing basis for a period not to exceed 120 days. To continue transportation service beyond the initial 120 day period, the blanket certificate holder must file an application under the prior notice procedures in section $157.205^{3}$ of the FERC's regulations and such application must be approved within the 120 day period.

Interstate pipelines transporting under Order No. 436 are subject to specific rate requirements. Any rate charged for a transportation service provided under Order No. 436 must be established under a rate schedule that is filed with the FERC prior to the commencement of such service. Rates must be one-part, volumetric rates which are cost-based. Such rates must also reflect any material variation in the costs of providing service due to whether the service is provided during a peak or an off-peak period and due to the distance over which the transportation is provided. Except for a reservation fee for firm service, rates may not include a demand charge, minimum bill, minimum take or any other provision that guarantees revenues. In calculating rates which conform to these conditions, an interstate pipeline must establish representative transportation levels, which can be changed in succeeding general rate proceedings.

Interstate pipelines may discount rates for transportation services. Minimum and maximum rates for each service provided must be stated in the pipeline's transportation tariff. Maximum rates must be designed to recover fully allocated costs of providing the service, while minimum rates are to be based on average variable costs for providing the service. While a pipeline may charge any rate that falls between the minimum and maximum rate, the FERC has indicated that the pipeline will bear the risk of any underrecovery of costs at rates discounted below the maximum.

Rates conforming to the above requirements must be filed by the interstate pipeline to be effective no later than July 1, 1986. Until conforming rates are established, pipelines transporting under Order No. 436 may charge an "interim" rate, provided that the interim rate is a onepart rate filed and included in an appropriate rate schedule filed with the 
FERC and effective prior to November 1,1985 . Such interim transportation rate must have been effective for transportation under Part 284 or section 157.209 of the Commission's regulations as they were in effect prior to the issuance of Order No. 436.

Order No. 436 also provides for "transitional" treatment of certain transportation arrangements which were commenced prior to October 9, 1985, the date of issuance of Order No. 436. Any transportation arrangement initiated under Part 284 of the Commission's regulations prior to October 9, 1985 may be continued under the terms and conditions that applied prior to October 9,1985, until the earlier of the expiration of the term of the transportation agreement as it was in effect on October 9, 1985 or October 9, 1987. Similarly, transportation arrangements which were commenced prior to October 9, 1985 under $\$ 157.209$ (a)(1) of the Commission regulations (transportation for high priority end-users) may continue for the full term of the underlying transportation agreement.

Continuation of service under such "grandfathered" arrangements is subject only to the new rate and reporting requirements of Order No. 436, and will not subject the transporting interstate pipeline to the nondiscriminatory access conditions of Order No. 436 nor the contract demand reduction/conversion options given to the pipeline's firm entitlement customers, as discussed below.

Limited transitional treatment is provided under Order No. 436 for transportation arrangements commenced for low priority end-users pursuant to $\$ 157.209$ (e) of the Commission's regulations prior to October 9, 1985. Such transportation arrangements may continue for the full term of the underlying contract only in the event that the interstate pipeline filed prior to November 1,1985 , a statement of notification that beginning on such date it would comply with the non-discriminatory access conditions of Order No. 436. Authorization to continue such services ceased on December 15, 1985, unless the pipeline filed for a blanket transportation certificate under Order No. 436 prior to that date.

One of the most controversial aspects of the transportation program created under Order No. 436 is the option granted to customers of interstate pipelines who participate in the program to reduce their firm sales entitlement or to convert their firm sales entitlement to firm transportation service (CD reduction/conversion option). The Commission's regulations enacted under Order No. 436 provided that any interstate pipeline that commenced a new transportation arrangement on or after December 15, 1985, would be "deemed to have agreed to offer its firm sales customers" the option to reduce the level of the customer's firm sales entitlement under any firm sales agreement with the pipeline which was entered into prior to the date that the pipeline elected to participate under Order No. 436.4 Similarly, the interstate pipeline is deemed to have agreed to offer each firm sales customer the option to convert a portion of its firm sales entitlement to a volumetrically equal amount of firm transportation service. 
The regulations originally enacted under Order No. 436 set up a transitional four-year period over which a firm entitlement customer may cumulatively reduce and/or convert $100 \%$ of its firm sales entitlement. Originally, the rules provided that without consent of the pipeline, a customer's combined reductions and conversions may not affect more than twenty-five percent $(25 \%)$ of the customer's firm sales entitlement in any twelve-month period during the transitional period. However, the reduction/conversion options are cumulative during the transitional period, and following the transitional period a customer may reduce or convert $100 \%$ of its firm sales entitlement at any time.

Subsequently, orders issued on rehearing of Order No. $436^{s}$ increased the transitional period from four to five years and modified the notice deadlines, effective dates, and percentages of permissible annual CD reduction/conversion options to establish a slightly more gradual phase-in period. Order No. 436-A established a five-year phase-in period, which caps $C D$ reduction/conversion adjustments at fifteen percent $(15 \%)$ for each of the first two years, twenty percent $(20 \%)$ for the third year, and twenty-five percent $(25 \%)$ for each of the last two years. ${ }^{6}$

Orders issued on rehearing of Order No. 436 also have delayed the CD reduction/conversion "trigger date" from December 15, 1985 to February $15,1986,{ }^{\prime}$ and subsequently to July $1,1986 .^{\circ}$ Interstate pipelines may transport under Order No. 436 for shippers who qualify under section 311 of the NGPA on an interim basis up to June 30,1986 without being deemed to have offered their firm entitlement sales customers the CD reduction/ conversion options. The Commission has clarified that an interstate pipeline may terminate on June 30,1986 all new section 311 transportation arrangements commenced on or after October 9,1985 , and thereby not be deemed to have offered the $C D$ reduction/conversion options to its customers, as long as it terminates all new arrangements in a nondiscriminatory manner. ${ }^{9}$

Intrastate pipeline companies commencing new transportation services on or after October 9,1985 under section 311 of the NGPA are deemed to have elected to participate under the "voluntary" Order No. 436 transportation program and become subject to the non-discriminatory access conditions. However, intrastate pipelines are not subject to the rate conditions of Order No. 436, nor are their firm entitlement sales customers provided with $C D$ reduction/conversion options. In addition, intrastate pipelines are not required to provide firm transportation service, although upon election to provide firm service, an intrastate must do so on a nondiscriminatory basis.

5. Supra n. 1, Order No. 436-A, issued December 12, 1985, 50 Fed. Reg. 52,217 (December 23, 1985), FERC Statutes and Regulations 961,036 ; Order No. 436-B, issued February 14, 1986, 51 Fed. Reg. 6,398 (February 24, 1986); Order No. 436-C, issued March 28, 1986, 51 Fed. Reg. 11 ,566 (April 4, 1986); Order No. 436-D, issued March 28, 1986, 51 Fed. Reg. 11,569 (April 4, 1986); Order No. 436-E, issued March 28, 1986, 51 Fed. Reg. 11,566 (April 4, 1986).

6. Id. at Order No. 436-A, FERC Statutes and Regulations at $31,671$.

7. Id. at FERC Statutes and Regulations at 31,650.

8. Id. at Order No. 436-B.

9. Id. 
[VOL. XXV, NO. 1

\section{B. INTERSTATE PIPELINE RESPONSE TO AND IMPLEMENTATION OF ORDER NO. 436}

Interstate pipelines have focused their criticisms of Order No. 436 on three major aspects of the final rule: (1) the alleged "voluntary" nature of the program; (2) the CD reduction/conversion options; and (3) the lack of Commission action on take-or-pay relief.

Interstate pipelines have taken the position that they are faced with a Hobson's choice in deciding whether or not to participate under the transportation program created by Order No. 436. The Commission has emphasized the "voluntary" nature of the program in defending its authority to prescribe the non-discriminatory access condition. ${ }^{10}$ The Commission has stated that interstate pipelines remain free to file traditional applications under section 7(c) of the NGA for transportation services which will not be covered by the non-discriminatory access condition, and the Commission will review such applications on a case-bycase basis. However, the Commission has clarified that such individual applications will be closely scrutinized to ensure that they do not serve as vehicles to perpetrate or perpetuate discrimination. "As a practical matter, an interstate pipeline which does not elect to participate under the "voluntary" program is deprived of all self-implementing transportation authority. Moreover, the Commission has established a practice of setting for hearing any section 7(c) transportation application that is protested on grounds of discrimination. ${ }^{12}$ Customers or potential shippers of any interstate pipeline can hold an individual section 7(c) application hostage for long periods of time. Thus, a pipeline who elects not to participate under Order No. 436 is faced with substantially decreased transportation revenues.

On the other hand, pipelines who do elect to participate are faced with potential increased take-or-pay liability associated with displacement of sales by transportation which is likely to occur as a result of the $C D$ reduction/conversion options granted to a participating pipeline's firm entitlement customers and the Commission's failure to address the take-orpay problem in the final rule in Order No. 436.13 The CD reduction/ conversion options have been uniformly attacked in the pending appeals of Order No. 436" as "unilateral" rights for distributors to breach their contracts with their pipeline suppliers and as beyond the Commission's authority. The Commission, while delaying the trigger date for the CD

10. Supra n. 1, FERC Statutes and Regulations at 31,501 .

11. See Texas Gas Transmission Corporation, 34 FERC 961,203 (1986) at $61,341$.

12. Id.

13. Supra n. 1, FERC Statutes and Regulations at 31,563-67. In issuing Order No. 436, the FERC decided not to promulgate Part B of the May 30th NOPR in Docket No. RM85-1-000. Instead, it reaffirmed its April 10, 1985 Statement of Policy concerning take-or-pay buyouts (50 Fed. Reg. 16,076, April 24, 1985, to be codified at 18 C.F.R. 52.76) and adopted a new policy on expedited producer abandonment. This new policy statement provides that the FERC will expeditiously review unopposed applications for abandonment of gas subject to take-or-pay relief or substantially reduced takes (to be codified at 18 C.F.R. 52.77).

14. Appeals of Order No. 436, et al. pending in the United States Court of Appeals for the District of Columbia Circuit have been consolidated in Associated Gas Distributors et al. v. FERC, D.C. Circuit No. 85-1811 et al. 
reduction/conversion options, ${ }^{\text {is }}$ has continued to maintain its position that such options are essential to achieving the goal of non-discriminatory access to transportation. Therefore, any interstate pipeline electing to participate under Order No. 436 is faced with the immediate prospect of granting its firm sales customers the $C D$ reduction/conversion options.

Faced with this choice, the majority of interstate pipelines have approached an election to participate under Order No. 436 cautiously. In the past several months, a number of interstate pipelines have injected an open-access proposal under Order No. 436 into settlement negotiations in their general rate proceedings. The advantage of implementing an election to participate under Order No. 436 through a settlement agreement is the opportunity to mold some of the provisions of Order No. 436 to the particular situation of a pipeline, its customers, and its potential shippers. Ambiguous provisions such as the first come, first served method of allocating capacity can be fine-tuned through the settlement process. Moreover, some pipelines are even attempting to obtain customer agreement to a further postponement of the CD reduction/conversion options.

While the Commission has demonstrated some willingness to entertain settlement proposals which substantially conform to the provisions of Order No. 436, an Energy Information Administration (EIA) study prepared for Congressman Dingell, entitled, "An Analysis of FERC Order No. 436", cautions the FERC that if it takes a non-generic approach to implementing Order No. 436, the result, instead of increased competition under an open transportation system, could be a long and tedious transition to a new and different system of regulation that may be no better than the current system. ${ }^{16}$

\section{IMPACT OF ORDER NO. 436 TRANSPORTATION ON THE CANADIAN AND U.S. NATURAL GAS INDUSTRIES}

As noted by the EIA study, the degree to which Order No. 436 affects the natural gas industry depends critically on the extent of participation in the program. Order No. 436 itself creates a transportation program with far greater flexibility than that of the Commission's earlier transportation programs by eliminating restrictions on the source, categories and end-uses of the gas to be transported, qualifications of shippers, and restrictions on the duration of transactions eligible for self-implementing transportation. For example, the blanket certificate and self-implementing provisions of Order No. 436 do not distinguish between the transportation of domestic and imported gas. ${ }^{77}$

As a result, demands for transportation of both imported and domestic natural gas by distributors, consumers, pipelines, producers, brokers and other marketers can be met by an interstate pipeline which elects to participate under Order No. 436. Pipelines are also allowed increased flexibility to respond to competition by selective discounting of transportation rates.

15. See supra nn. 6 and 7 and accompanying text.

16. See Inside F.E.R.C. (April 21, 1986) at 1 and 4.

17. See supra n. 5, Order No. 436-A, FERC Statutes and Regulations at 31,688-89. 
[VOL. XXV, NO. 1

Widespread participation by interstate pipelines under Order No. 436 could result in the wellhead market and the market for imports becoming available to many new buyers. Distribution companies, end-users and marketers with ready access to transportation could increase competition in these markets by exercising their options for the direct purchase of natural gas, exerting additional downward pressures on natural gas prices. ${ }^{18}$ Widespread participation under Order No. 436 could open up previously dedicated markets, providing strong incentives to all market participants to renegotiate long-term contracts. ${ }^{19}$

\section{BLOCK BILLING}

In its final rule in Order No. 436, the FERC chose not to implement the "block billing" mechanism proposed in Part D of the May 30th NOPR. ${ }^{20}$ Instead, the Commission issued on October 9, 1985, a Notice Requesting Supplemental Comments' ${ }^{21}$ on a revised block billing proposal, similar to the original. The revised proposal, like the original, would eliminate traditional rolled-in pricing of a pipeline's purchased gas costs and would create separate blocks for this purpose. The revised proposal would eliminate a previously proposed third block, modify the basis for allocation of Block 1 gas costs to pipeline customers, and make a number of modifications with respect to implementation.

The revised proposal contemplates establishment of two blocks: Block 1 would include NGPA sections 104, 106(a) and 109 gas ("old" gas), while Block 2 would include all other NGPA gas plus commodity charges for imported gas. In eliminating the previously proposed Block 3 , which was intended to preserve the "as-billed" principle for fixed costs, the Commission clarified that demand charges from upstream domestic suppliers would continue to be flowed through the demand charge of the purchasing pipeline, while demand charges for Canadian gas purchases would be reviewed on a case-by-case basis. ${ }^{22}$ The proposed difference in treatment for domestic and Canadian supplies has drawn sharp criticism from the Department of Energy (DOE), which has commented that it sees no rationale for not treating Canadian supplies on an equal basis with domestic supplies. ${ }^{23}$

The block billing mechanism, both as originally proposed and revised, has drawn almost unanimous criticism from commenters. As a result, the DOE has suggested an alternative to the block billing proposal, which has engendered just as much criticism from interstate pipeline companies. (See discussion of Order 451, infra.)

18. See supra n. 16.

19. Id.

20. Supra n. 1.

21. Notice Requesting Supplemental Comments, issued October 9, 1985, Docket No. RM85-1000 (Part D), 50 Fed. Reg. 42,372 (October 18, 1985).

22. Id., mimeo at 69-70.

23. Comments of the United States Department of Energy, Docket No. RM85-1-000 (Part D), November 18, 1985 at 7. 


\section{DISPLACEMENTS AND EXCHANGES}

The FERC has always included displacement and exchange arrangements within its definition of "transportation" under the FERC's exercise of authority under sections 1 and 7 of the NGA. Displacements and exchanges both serve to effect a non-physical "movement" of natural gas from one point to another.

In attempting to define transportation by exchange, the FERC has stated that: ${ }^{2 s}$

Transportation by exchange occurs when two companies each have gas supplies remote from their system but connected to the system of the other company. Each pipeline receives the gas belonging to the other, with imbalance volumes received being adjusted through deliveries at a third point. An exchange makes possible a "movement" of gas between two points which do not have connecting pipeline facilities.

Central to the definition of "exchange" is the idea of reciprocal benefit or the trade of comparable values..$^{23}$ On the basis that an exchange arrangement is beneficial to each of the participants, in that it provides a means of delivering gas supplies to their customers without the necessity of constructing and operating duplicative facilities, ${ }^{26}$ the Commission has allowed a majority of exchanges to occur on a "no fee" basis, without each of the pipeline companies involved charging the other its generally applicable transportation rates for the service. If the gas exchanged by one pipeline is not of equal value to the gas exchanged by the other pipeline, because one pipeline has less gas and/or that gas is of lower quality, the pipeline receiving the lesser-valued gas volumes may also receive a fee. ${ }^{27}$

Transportation by displacement, on the other hand, involves the "movement" of natural gas volumes from one point on a pipeline's transmission system to another, noncontiguous point on that pipeline's system. Displacement permits a lateral movement of gas through a transportation network. While the configuration of some pipeline systems is such that it may not be readily apparent whether the given movement of gas is forward or backward from the point of receipt, the gas is nevertheless received and delivered by the pipeline using its own facilities to provide the service. ${ }^{23}$ In contrast to exchange services, transportation rates are normally charged for displacement services.

The benefit of exchange services in the marketing of natural gas is obvious. An exchange arrangement provides a means for delivering remote gas supplies to a market without the necessity or expense of constructing and operating duplicative facilities. Moreover, an exchange arrangement is often the least expensive, and therefore most desirable, form of transportation service. An exchange arrangement with another pipeline may eliminate the need to pay for front-haul transportation over hundreds of miles to move a remote gas supply to a desired market. ${ }^{29}$

24. Tennessee Gas Pipeline Company, 23 FERC 961,115 (1983) at 61,270.

25. Tennessee Gas Pipeline Company, 26 FERC $\$ 61,255$ (1984) at 61,573.

26. See Columbia Gas Transmission Company, 5 FERC 161,249 (1978).

27. See supra n. 1 at Order No. 436, Docket No. RM85-1-000 (Parts A-D) (October 9, 1985), 33 FERC 961,007 (1985), FERC Statutes and Regulations $\{30,665$ at $31,505$.

28. Id. FERC Statutes and Regulations at $31,507$.

29. Id. at 31,506. 
Displacement transactions also permit efficient delivery of natural gas, often at substantially lower transportation rates than that charged for forward-haul transportation services. The FERC has noted that displacement arrangements are "widespread and commonplace" for that reason..$^{30}$

The Commission has clarified in Order No. $436^{31}$ that the nondiscriminatory access conditions of Order No. 436 apply to transportation by exchange and transportation by displacement.

With respect to exchanges, most pipeline commenters that have specifically addressed the issue contended that exchanges should not be subject to the non-discriminatory access condition. In essence, the pipelines argued that the opportunities to effectuate a transaction via an exchange are factspecific and, therefore, difficult to subject to the application of uniform rules. They have also contended that subjecting exchanges to the nondiscriminatory access condition could remove operational and dispatching decisions from the pipeline managements, since requiring pipelines to seek out the most efficient exchange arrangements would probably result in hearings to determine if an alternate transportation routing would have been preferable. ${ }^{32}$

Commenters taiking the opposite position have argued that they ought not to be forced to pay for an expensive forward-haul transaction when the transporting pipeline might be able to effectuate the same transaction via an exchange with another pipeline."

The Commission, while stating its agreement to a large degree with each of the opposing positions, clarified that Order No. 436 would continue to include exchanges within the definition of transportation, and, because of their efficiencies and benefits, exchanges would be subject to nondiscriminatory access conditions. The Commission, acknowledging the arguments of the pipeline commenters concerning operational constraints, added the caveat that a pipeline may wish to file with its tariffs "definitions of those types of non-recurring exchange transactions that it proposes to be exempt from the non-discriminatory access condition". ${ }^{34}$ The Commission will review such definitions as part of its case-by-case review of each pipeline's tariffs.

In view of the fact that the majority of interstate pipeline companies have not yet filed tariffs that comply with Order No. 436, it is difficult to predict the success pipelines may have in carving out certain types of exchanges from the non-discriminatory access conditions of Order No. 436. To the extent that more pipelines elect to participate under the Order No. 436 transportation program, shippers will have opportunities which previously existed only on a limited basis to effectively "move" gas across long distances to their markets without the expense of forward haul transportation. This, in turn, will make competitively priced natural gas located at great distances from a pipeline's traditional market much more attractive.

30. Id. at 31,507.

31. Id. at 31,505-08.

32. Id. at 31,506.

33. Id.

34. Id. 
Local distribution companies and "Hinshaw" pipeline companies [NGA s. 1(c)] may take advantage of exchange transactions as well under the provisions of Order No. 436. Such entities may apply for a blanket transportation certificate under Order No. 436 which will, inter alia, allow them to exchange gas with interstate pipeline companies to the same extent that intrastate pipeline companies can engage in such activities under the provisions of section 311 of the Natural Gas Policy Act and the Commission's regulations under Order No. 436. ${ }^{35}$

The widespread availability of exchange transactions to move remote supplies of competitively priced gas to market could have widespread implications for the marketing of Canadian gas. Pipelines, local distribution companies, and "Hinshaw" pipelines with markets in the southern United States, by entering into exchange transactions with transmission companies with facilities at the Canadian border and traditional markets in the northern United States, can import Canadian natural gas and exchange it with the other entity's Gulf Coast or Southern United States supplies, obviating the need for each entity to incur transportation costs to move its remote supply to market. Widespread availability of such exchanges could create an increased market for Canadian gas in parts of the United States heretofore inaccessible to Canadian supplies.

\section{MINIMUM BILLS}

\section{A. BACKGROUND}

"Minimum bills" refer to pipeline tariff provisions which require a customer to pay a portion of the pipeline's gas commodity charge regardless of whether the customer actually purchases that quantity of natural gas from the pipeline. Minimum bills have resulted from the fact that there are generally two types of customers on a pipeline system: full requirements and partial requirements. Full requirements customers, also known as captive customers, are so named because they purchase their entire natural gas supply from one pipeline. Partial requirements customers, as the name implies, are customers who are able to purchase their natural gas supplies from more than one source. As a result, they purchase only their partial requirements from any one pipeline and are able to "swing" from one supplier to another. The existence of both types of customers on a single pipeline system creates some rate making difficulties: ${ }^{36}$

There is some tension inherent in the relationship between full and partial requirements customers. .. . Interstate pipeline systems were designed based on the estimated markets of both full and partial requirements customers. Large scale investments were made to provide physical facilities and long-term supplies of gas to serve both groups. Costs reflecting these commitments have therefore traditionally been considered the responsibility of both groups....

Partial requirements customers have the ability to swing off the system, causing a reduction in expected sales volumes which, in turn, creates an underrecovery of costs. If the pipeline is unable to make up the lost volumes by selling the excess supply elsewhere, it

35. See 18 C.F.R. \$284.244.

36. Order No. 380, Elimination of Variable Costs from Certain Natural Gas Pipeline Minimum Commodity Bill Provisions, issued May 25, 1984, 49 Fed. Reg. 22,778 (June 1, 1984), 27 FERC 961,318, FERC Statutes and Regulations 930,571 (May 25, 1984) at 30,960. 
may file new rates to offset the decreased sales. In these new rates, the pipeline's fixed costs will be spread over the lower volumes the pipeline expects to sell, resulting in higher rates on that system. Although the higher rates will apply to all customers, the captive customers have no alternative to paying these rates, at least in the short run, while the swing customers (absent a minimum commodity bill) can avoid higher commodity charges.

The purpose of a minimum bill, then, is to ensure that the pipeline seller recovers its costs associated with serving a customer that can swing from one supplier to another. When the customer swings off the system, the pipeline supplier experiences a reduction in the sales volumes that were used to derive the rates. Thus, the pipeline underrecovers its costs absent a minimum bill provision. As a result, the remaining customers on the system may be required to pay a higher rate. Minimum bills are designed as a result of this problem.

However, the FERC has recognized that minimum bills are also inherently anticompetitive::77

The Commission has also recognized, however, that minimum commodity bills operate as a substantial barrier to competition because they force partial requirements customers to forego the purchase of less expensive gas from another supplier. In the long run, then, minimum bills could result in higher rates for all customers on a pipeline system by isolating the major supplier from market competition and reducing its incentive to minimize costs and prices.

(Citations omitted.)

In balancing the anti-competitive effects of minimum bills with the need to protect the pipeline's full requirements customers from rate impacts resulting from swings off the system, the Court in Lynchburg Gas Co. v. FPC held that the Commission could not assume that the elimination of a minimum bill would result in such a deterioration of a pipeline's markets as to increase the general rates: ${ }^{38}$

In particular, we held that the Commission could not simply assume that a particular minimum bill reasonably accommodated the competing interests of a pipeline supplier's customers without an evidentiary showing that the supplier could not accommodate swings without raising its rates and that specific captive customers will suffer the consequences of increased rates ... . We also concluded that the Commission must ensure that the particular minimum bill before it is carefully designed to balance the conflicting interests of full and partial requirements customers and that it is "no more restrictive than necessary". (Citations omitted.)

As a result, the Commission determined three standards that could justify a minimum bill: ${ }^{39}$

(1) the recovery of that portion of a pipeline's rates which allocates fixed costs to the commodity component;

(2) the protection of customers with no alternate supply from having to bear the costs of facilities constructed for a customer which obtains an alternative source; and

(3) [the recovery of] the minimum take or pay obligation which a pipeline has to its suppliers.

On appeal the D.C. Circuit determined that the minimum bill must be specifically designed to protect the supplier and its customers from the harsh effects of the competition resulting from partial requirements customers switching to another supplier: ${ }^{40}$

37. Mississippi River Transmission Corporation v. FERC, 759 F.2d 945 at 949 (D.C. Cir. 1985).

38. Lynchburg Gas Co., 336 F.2d 942 (D.C. Cir. 1964) as discussed in Mississippi River Transmission Corp., id. at 949.

39. Atlantic Seaboard Corp., 38 F.P.C. 91 at 95 (1962).

40. Atlantic Seaboard Corp. v. FPC, 404 F.2d 1268 at $1272-73$ (D.C. Cir. 1968). 
[A] policy favoring effective competition necessarily brings with it the reality of economic pinch, present or threatened. The presence of a second seller means that the historic supplier loses out on sales it would have otherwise had. . . . It is through the enhanced efforts made by the supplier in response to such pressure that competition reaps its benefits. The hard problem then is not whether competition may hurt but rather where and how to draw the lines of acceptable range of competition and hurt, in response to the economic characteristics and interrelationships of the industry that require regulation in the first place.

\section{B. ORDER NO. 380}

On May 25, 1984, the Commission issued Order No. 380,41 which eliminated variable costs from natural gas pipeline minimum commodity bill provisions. The Commission found under sections 4 and 5 of the Natural Gas Act that the use of a minimum commodity bill to recover variable costs is anticompetitive and can result in rates and charges that are unjust and unreasonable.

First, the Commission determined that a minimum bill provision allows the pipeline to recover costs that were not incurred: ${ }^{12}$

By definition there are no variable costs incurred for volumes not purchased for resale. Accordingly, a minimum commodity bill that includes variable costs gives a pipeline the right to collect for 'costs' it has not in fact paid out to provide jurisdictional natural gas service. On its face then, a minimum bill that permits such "cost" collection is unjust and unreasonable.

Next, the Commission found that minimum bills act as a restraint on competition. This finding was based on five factors.

The first factor was that variable costs in minimum bills insulate pipelines and producers from market risk which inhibits decreases in price. The Commission stated that variable costs in minimum bills block communication between producers, pipelines, distributors and ultimate consumers: ${ }^{40}$

When distributors and pipelines are required to purchase gas under a minimum commodity bill, even when less expensive sources aro available, the supplier pipeline can continue to operate profitably without having to worry about keeping its gas costs at a reasonable level. Thus, minimum commodity bills result in gas prices being 'propped' . . . at levels higher than the market would otherwise support.

The Commission further discussed the impact on the ability of sellers in an unregulated market to exchange price for volume. A pipeline cannot offer to increase sales volumes in exchange for a lower price when it has minimum bill volume obligations with another supplier: ${ }^{\wedge}$

Thus, minimum commodity bills can act to deprive producers of the opportunity to increase sales volumes in exchange for accepting a reduction in price.

The second factor considered was that minimum bill provisions prevent purchasers from pursuing a least-cost purchasing policy. Purchasers must take higher priced gas from suppliers with minimum bill requirements when lower priced gas is available.

The Commission discussed the third factor, namely, that variable costs in minimum bills lead to load loss in the natural gas industry. The
41. Supre n. 36.
42. Id. at 30,962 .
43. Id. at 30,963 .
44. Id. at 30,964 . 
artificially high prices resulting from minimum bill provisions create an incentive for some customers to switch to alternative fuels. This switch results in greater fixed cost responsibility for the remaining customers residential and small commercial customers.

The fourth factor dealt with the traditional justifications for minimum bills. These justifications are fixed cost recovery, equitable cost recovery, and take-or-pay recovery. The Order points out that these justifications are linked to traditional rate design methodologies. The minimum bill provisions have been utilized to ensure fixed cost recovery through the commodity rate. Today, most pipelines utilize the modified fixed-variable rate design which permits recovery of more fixed costs in the demand charge. Thus, the need for minimum commodity bill provisions to recover fixed costs is diminished. Although the Commission recognized that not all pipelines use the modified fixed-variable rate design, they noted that the elimination of variable costs does not affect the fixed cost recovery of these pipelines.

In addressing the risk of cost-shifting among customers and take-or-pay exposure the Commission noted:"s

... While this rule may result in short-term shifts in markets that could be detrimental to some customers, in the long-term there should be benefits to all customers of all pipelines as the industry moves towards a competitive market.

The Commission found that the traditional justifications do not justify the collection of gas costs by use of a minimum bill provision.

The final factor considered by the Commission was that the recovery of variable costs in minimum bills violates the mandate of the Natural Gas Act, in that the Natural Gas Act mandates protection of consumers from excessive rates and charges. To the extent that minimum bills are anticompetitive, they violate this mandate. Thus, minimum bills that contain variable costs are unjust and unreasonable rates or charges.

Although the Commission considered eliminating minimum bills entirely, it declined to do so at this time. The Commission stated that it "intends to assess the impact of removal of variable costs from minimum commodity bills before it takes any further generic steps on this subject".

Since the issuance of Order No. 380, the Commission has taken no more generic steps on the issue of minimum bill. However, the minimum bill issue has been the subject of much litigation.

\section{FATE OF MINIMUM BILLS FOLLOWING ORDER NO. 380}

After Order No. 380, any remaining minimum bills contain only fixed costs.

In Transwestern Pipeline Company, the Commission stated:45

That we have ordered pipelines to modify their minimum bills to exclude variable costs from the commodity rate and eliminate physical take provisions does not mean we can assume the minimum bills that remain, such as Transwestern's, are reasonable and lawful. They still may adversely affect competitors and consumers by foreclosing competition and restraining trade. 
The Commission again identified the three factors that could justify a minimum bill: (1) to protect the pipeline against the risk of not recovering the fixed costs in the commodity component; (2) to protect full requirements customers from bearing a disproportionate share of the fixed costs resulting from swings off the system by partial requirement customers; and (3) to protect customers from take-or-pay liabilities the pipeline might otherwise incur. ${ }^{47}$

Using these factors the Commission determined that Transwestern's minimum bill was unlawful. The same result was reached in Southern Natural Gas Company "s and Natural Gas Pipeline Company of America."9 In Colorado Interstate Gas Company, ${ }^{30}$ the minimum bill provision was upheld. In this case, CIG had a minimum bill provision that recovered both fixed and variable costs. The Commission applied the three standards and determined that a minimum bill limited to the recovery of fixed costs would be just and reasonable.

Therefore, the final conclusion with regard to minimum bills is uncertain. However, as the Commission noted in Transwestern:

The effect of a minimum bill is to restrain trade, for it forces a customer to buy gas from one pipeline rather than other pipelines, thereby foreclosing competition for that customer's business.

A pipeline must overcome that hurdle by applying the three standards found to justify a minimum bill to its particular situation.

\section{V. “AS-BILLED” PASSTHROUGH OF CANADIAN GAS COSTS}

One regulatory issue, which also involves the issue of the division of regulatory responsibility between the FERC and the Economic Regulatory Administration of the Department of Energy (ERA), has arisen in several U.S. pipelines' Purchased Gas Adjustment (PGA) or general rate proceedings where the pipeline has attempted to flow through charges from Canadian suppliers based on two-part demand/commodity rate design on an "as-billed" basis to the U.S. pipeline's customers. In each instance, the Canadian gas import contracts were renegotiated to include a two-part rate design as a result of the departure of the National Energy Board of Canada (NEB), in July, 1984, from its previous uniform border price policy in favour of giving exporters the option of negotiating more competitive individual arrangements, subject to NEB review. In their PGA or general rate filings, importing U.S. pipelines have requested authority to flow through the demand costs of the Canadian supplies in their demand rates and the commodity costs in their commodity rates.

The "as-billed" passthrough of charges of U.S. domestic pipeline suppliers is a long-standing FERC practice. With respect to methods of determining changes in cost of gas purchased by U.S. pipeline companies

47. Id. at 61,031 .

48. 32 FERC 961,477 (1985).

49. 31 FERC 961,380 (1985).

50. (CIG) 27 FERC 961,315 (1984).

51. Supran. 46 at 61,030 . 
from producer and pipeline suppliers, section 154.38(d)(4)(ii) of the FERC regulations governing PGA clauses provides that: ${ }^{52}$

Producer rate changes shall be applied to the commodity component of the existing rates of a pipeline company's two-part rates and to the volumetric rates of a pipeline company's one-part rates. Pipeline supplier rate changes shall be applied "as-billed" to a pipeline company's two-part rates and shall be applied to a pipeline company's volumetric rates in the manner which maintains the pipeline company's existing one-part rate design.

Some U.S. pipeline companies have requested waiver of this regulation in order to treat Canadian non-pipeline suppliers' demand charges identically to pipeline supplier demand charges. The rationale for this proposed treatment is based on an analogy between the Canadian suppliers, who are technically producers or resellers, to pipeline suppliers based on the fact that the Canadian supplier incurs costs to have the gas transported and delivered to the Canadian border and therefore functions in a comparable manner to a pipeline supplier.

The FERC has denied automatic passthrough and set for hearing the proposals of a number of U.S. pipeline companies to flow through demand and commodity charges of Canadian suppliers to their U.S. customers on an "as-billed" basis. ${ }^{33}$ Protestors to such proposals have argued that while the FERC may permit automatic collection of domestic demand and commodity charges in the purchasing pipelines' rates, there is no reason to extend this treatment to imported gas. ${ }^{44}$ Protestors have also argued that all or a portion of the demand charges of the Canadian suppliers may in fact be gas costs, which the Commission has allowed to be recovered only in commodity rates. ${ }^{\text {s }}$ Concern has been expressed that to allow producer gas costs to be recovered in demand rates would enable producers and purchasing pipelines to shift costs to small consumers through increased pipeline demand costs." The FERC staff has opposed "as-billed" passthrough of Canadian gas costs on the basis that the FERC imposes standards on the demand charges of U.S. pipelines not only as to cost classification, cost allocation and rate design methodology, but also as to the appropriateness of underlying costs. Staff has argued that in this regard U.S. pipelines are kept on an equal competitive footing but, by contrast, "as-billed" passthrough of Canadian demand charges over which the FERC exercises no control would confer an unfair competitive advantage on Canadian suppliers."

Faced with such protests, several U.S. pipeline companies have responded to FERC orders setting the propriety of "as-billed" passthrough of Canadian gas costs for hearing by turning to the ERA.

52. 18 C.F.R. $\$ 154.38(d)(4)(i i)$.

53. Transcontinental Gas Pipe Line Corp., Docket Nos. TA85-1-29, et al., 29 FERC 961,148 (1984); Northwest Pipeline Corporation, Docket Nos. TA85-2-37, et al., 29 FERC $\$ 61,149$ (1984); Boundary Gas, Inc., Docket Nos. RP85-112-000, 30 FERC 961,345 (1985); ANR Pipeline Company, Docket No. TA85-2-48, et al., 31 FERC 961,127 (1985); Natural Gas Pipeline Co., Docket Nos. TA85-1-26, et al., 31 FERC 961,190 (1985); Texas Eastern Transmission Corp., Docket Nos. TA85-4-17, et al., 32 FERC 161,079 (1985); Tennessee Gas Pipeline Company, Docket Nos. 86-2-9, et al., 33 FERC 961,473 (1985).

54. See, e.g., Transco, id. at 29 FERC at $61,321$.

55. See, e.8., Natural, id. at 31 FERC at 61,391 .

56. Id.

57. See Transcontinental Gas Pipeline Corporation, Docket No. TA85-1-29-005, 32 FERC $\{63,081$ (1985) (initial decision). 
Northwest Pipeline Corporation (Northwest) was the first U.S. pipeline company to petition the ERA and receive a favourable rulings" on the "asbilled" issue in response to a FERC order setting the issue for hearing. Northwest had entered into a letter agreement dated October 1, 1984 with its Canadian supplier, Westcoast Transmission Company Limited (Westcoast). The agreement established a two-part, demand-commodity pricing structure. Northwest filed a report of contract amendments with the ERA on October 4,1984 , in accordance with the requirements of $\$ 590.407$ of the ERA's administrative procedures. Northwest then applied to the FERC to amend its PGA to track in its rates any future changes in the Westcoast demand and commodity charges. On October 31, 1984, the FERC set the "as-billed" passthrough issue for hearing. ${ }^{59}$ In response to concerns raised by the customers of Northwest, on April 30, 1985, the FERC broadened the scope of the hearing to include an issue relating to the prudency of Northwest's agreement with Westcoast. ${ }^{\circ}$

Northwest responded by filing a petition with the ERA on May 10, 1985, requesting that the ERA "issue an order finding that the Westcoast Agreement, covering the 1984-85 contract year, including the two-part rate structure and the reduced average unit price, to be not inconsistent with the public interest and, in all aspects, in conformance with the DOE Guidelines respecting the importation of natural gas". 61

Intervenors opposing Northwest's application contended that the twopart, demand-commodity pricing structure and the "as-billed" passthrough provision of the Northwest-Westcoast agreement were unfair to them as U.S. customers of Northwest, because they had cheaper domestic gas available and because FERC Order No. $380^{62}$ allowed them to avoid paying the commodity charge for any gas they did not take. The opponents argued that under a one-part rate structure, they could avoid any commodity charge for the Westcoast gas not taken, while a two-part rate would result in higher demand charges than before since Northwest's demand charges to its customers would include the "as-billed" passthrough of Westcoast's demand charges. ${ }^{63}$

Northwest argued that the two-part rate structure was an integral part of the Northwest-Westcoast letter agreement in that negotiation of a longer term agreement continued to be based on the assumption that two-part. rates would be approved. Northwest also argued that the Department of Energy had recently indicated in its comments filed in the FERC Notice of Proposed Rulemaking issued in Docket No. RM85-1-000 (Part D) that two-part rate structures for the importation of Canadian gas are "consistent with U.S. import policy" is

After accepting comments on Northwest's application and convening a conference to address the concerns of the intervenors, the ERA in DOE/

58. See Northwest Pipeline Corp., DOE/ERA Opinion and Order No. 87 (September 10, 1985).

59. See Northwest Pipeline Corporation, supre n. 53 at 61,323.

60. Northwest Pipeline Corp., Docket Nos. TA85-3-37, et al., 31 FERC 961, 128 (1985) at 61,259.

61. Application of Northwest Pipeline Corporation, ERA Docket No. 85-12-NG, at 17.

62. Supra n. 36; see also text of Part IV, supra.

63. See supra n. 58 at 10.

64. Id. 
[VOL. XXV, NO. 1

ERA Order No. 87, issued on September 10, 1985, found "that the twopart, demand-commodity pricing structure, with the gas costs passed through on that basis, is reasonable and consistent with the public interest". ${ }^{65}$ The ERA also found that the Northwest amendment provided natural gas that was more competitive in the markets served by Northwest than under the previous arrangement and thus was in conformity with the public interest test established in section 3 of the NGA and the DOE policy guidelines. ${ }^{\circ}$

With respect to the issue of the relationship between the ERA and the FERC under the NGA and the impact of the parallel FERC proceeding on the Northwest-Westcoast contract, the ERA noted that the Administrator of the ERA is delegated the sole authority to authorize imports under the NGA by the Secretary of Energy under the Department of Energy Organization Act. The ERA pointed out that in Delegation Order No. 0204-111, the Administrator is delegated the authority under section 3 of the NGA to regulate imports of natural gas based on a consideration of such matters as the Administrator finds to be appropriate, and that in exercising that authority the Administrator may attach such terms and conditions as he may determine to be appropriate. In contrast, the FERC is delegated the responsibility in Delegation Order No. 0204-112 with respect to the regulation of imports to issue orders, authorizations, and certificates which the FERC determines to be necessary or appropriate to implement the determinations made by the Administrator. The ERA further noted that the DOE policy guidelines direct the FERC to act consistently with the determinations made by the Administrator and the policy considerations reflected in the Administrator's authorization.

The ERA also quoted for support an opinion of the U.S. Court of Appeals for the District of Columbia Circuit, which stated:67

\section{Pursuant to the section 3 power delegated to it by the Secretary, the Commission is empowered to exercise its section 4 and 5 powers over imported gas. The only limit placed upon this authority is that the Commission cannot, consistent with the Delegation Orders, take actions inconsistent with the terms, conditions, or policy considerations reflected in the ERA's section 3 import authorization.}

Based on the foregoing analysis, the ERA concluded that it was "clear" that once the Administrator has approved an import arrangement, "the FERC, while exercising its section 4 and 5 authorities, cannot act in a manner inconsistent with the actions taken by the Administrator." ${ }^{63}$

In applications for rehearing of ERA Opinion No. 87, Northwest's U.S. customers argued that the ERA had encroached on the authority and matters vested in the FERC and had exceeded its jurisdiction by imposing on the FERC a specific ratemaking treatment for Northwest's costs. In its order denying rehearing, ${ }^{, 9}$ the ERA declined to clarify or otherwise change its language in Order No. 87 on the jurisdictional issue. It did note,

65. Id. at 11.

66. Id. at 14.

67. Id. at 16 quoting Wisconsin Gas Co. v. FERC, 770 F.2d 1144 at 1155-56 (D.C. Cir. 1985).

68. Id. at 17. See also, Appendix " $A$ ", infra, "Jurisdictional Division of Authority Between the Federal Energy Regulatory Commission and the Economic Regulatory Administration".

69. Northwest Pipeline Corporation, DOE/ERA Opinion and Order No. 87A Denying Rehearing (November 8, 1985). 
however, that in dealing with and approving the "as-billed" passthrough provision of the exporter-importer agreement and the two-part rate structure as being in the public interest, it was exercising its authority under section 3 of the NGA and not exercising any authority under sections 4 or 5 of the NGA delegated by the Secretary to the FERC. The ERA stated that insofar as interstate ratemaking implications of the import arrangement were concerned, it was up to the FERC to exercise its authority under sections 4 and 5 of the NGA while acting in a manner consistent with the Secretary's delegation orders, departmental policy as contained in the DOE guidelines and DOE/ERA opinions and orders. ${ }^{\text {T }}$

The ERA has addressed the "as-billed" issue more recently in an order authorizing Texas Eastern Transmission Corp. (Texas Eastern) to amend its contract with a Canadian supplier, ProGas Ltd (ProGas), to reduce its minimum annual take-or-pay obligation and to replace a volumetric rate with a two-part demand/commodity pricing formula subject to adjustments based on fuel oil prices." Protestors to Texas Eastern's application contended that the proposal to split the former one-part commodity charge for Canadian gas into a two-part demand/commodity rate, and any passthrough of such charges "as-billed", was unfair and anticompetitive. The ERA in its order rejecting such allegations, noted that the arrangement was similar to domestic pipeline arrangements that utilized two-part rates and reflected the cost of providing transportation over long distances. The ERA found that ProGas operated much like a gas pipeline since it purchased gas in Canada and then arranged and paid for transporting it to the U.S. for resale. The ERA concluded that it saw no basis for not approving a two-part rate when it is used in arrangements comparable to domestic gas supply arrangements, stating that: ${ }^{n}$

It is the ERA's position, and the policy of the DOE, that since U.S. pipelines utilize and pass through two-part demand/commodity rates as billed, to avoid discrimination, Canadian natural gas shbuld be afforded the same opportunity to compete in U.S. markets. (Footnote omitted.)

With respect to what it termed a "collateral legal matter" concerning the ERA's jurisdiction to approve the "as-billed" passthrough of the two-part rate in Texas Eastern's application, the ERA reaffirmed its discussion of the issue in its final decision and rehearing in the Northwest case. However, the ERA then stated that while it endorsed in principle the passthrough of the two-part structure of the arrangement, such endorsement did not necessarily extend to "every single cost element exactly as proposed". ${ }^{3}$ In explanation of its position, the ERA stated: ${ }^{74}$

It is up to the FERC to exercise its authority under Sections 4 and 5 of the NGA, while acting in a manner consistent with the ERA's decisions and the DOE's policies. Clearly, if there are components of a demand charge, such as production-related costs that the FERC would not permit to be treated as fixed costs, the Canadian import should be

70. Id. at 14.

71. Texas Eastern Transmission Corp., DOE/ERA Opinion and Order No. 112 (March 21, 1986).

72. Id. at 13-14, citing Comments of the United States Department of Energy, FERC Docket No. RM85-1-000 (Part D), November 18, 1985, at 7.

73. Id. at 17.

74. Id. 
treated no differently. However, if the international contract, freely negotiated by commercial parties and approved by the ERA, includes cost recovery provisions that achieve reasonable results and are in compliance with applicable laws, the ERA urges regulatory restraint from any unnecessary intrusion into private contract matters.

While the FERC has not yet addressed the ERA's position on the "asbilled" issue in any of the proceedings in which that issue was set for hearing, ${ }^{75}$ the FERC administrative law judges which have issued initial decisions in two of those proceedings have recommended approval of proposals to flow through two-part rates for Canadian gas on an "asbilled" basis.

Administrative Law Judge Thomas I. Megan, in an initial decision issued on September 3,1985, ${ }^{16}$ recommended that the Commission grant a requested waiver of its PGA regulations to allow Transcontinental Gas Pipe Line Corporation (Transco) to flow through demand and commodity charges of its Canadian supplier, Sulpetro Limited (Sulpetro) on an "asbilled" basis.

Transco and Sulpetro had entered into an amended agreement on June 28,1984 which provided for the continued sale of Canadian volumes under a two-part demand-commodity rate structure. On October 31, 1984, the ERA issued Opinion and Order No. 46A approving Transco's application to amend its authorization to import Canadian gas from Sulpetro to reflect the terms of the amended agreement; and finding that the amended contract met the public interest requirement of section 3 of the NGA as embodied in the policy guidelines announced in the Secretary of Energy's February, 1984 new policy guidelines and delegation orders. When Transco then attempted to flow through its purchased gas cost from Sulpetro on an "as-billed" basis, the FERC set the "as-billed" issue for hearing."

Administrative Law Judge Megan, in recommending that Transco be allowed to pass through Sulpetro's charges on an "as-billed" basis, acknowledged that the Alberta gas involved was transported some 2500 miles to the border at Niagara Falls and that Sulpetro's charges to Transco represented a passthrough of the demand charge which Sulpetro paid TransCanada for firm transportation service from the Alberta-Saskatchewan border to the U.S. border near Niagara Falls. He concluded that Sulpetro, while also a producer, acted like a pipeline supplier under these circumstances. He also found it significant that the NEB and ERA had approved the amended agreement and that the NEB had changed its export policy from one-part commodity rates so as to permit the two-part rate design negotiated by the parties.

Noting that this was the first case to come before the FERC where the new Canadian export policy was involved, Administrative Law Judge Megan concluded that the public interest would best be served by approving arrangements of this kind, rather than "seizing upon this circumstance as a means to strike down the passthrough and establish a road block to further efforts in this regard". ${ }^{78}$

75. See supra n. 53.

76. Transcontinental Gas Pipe Line Corp., Docket No. TA85-1-29-005, 32 FERC 963,081 (1985).

77. Id. at 65,261-262.

78. Id. at 65,263 . 
On March 18, 1986, Administrative Law Judge Brenda P. Murray issued an initial decision in Boundary Gas, Inc.s (Boundary) rate proceeding in Docket No. RP85-112-000 permitting Boundary to passthrough its gas costs from its Canadian supplier, TransCanada Pipelines Limited (TransCanada) to its U.S. customers on an "as-billed" basis."

In response to the Canadian pricing policy change made in July, 1984 and the issuance of the DOE's new policy guidelines in February, 1984, Boundary and TransCanada amended their gas purchase contract on March 4, 1985 to eliminate a two-block volumetric rate design with a minimum bill provision. The renegotiated agreement contained a demand rate and seasonal commodity rates with no minimum bill other than the demand charge. Canada's Governor-In-Council approved the renegotiated contract on April 4, 1985. Boundary made an informational filing with the ERA on March 5, 1985 because it believed the amended contract was within its existing section 3 import authorization. The ERA acknowledged the filing on March 15, 1985 and reserved its authority to take action on the amended contract, but had taken no action as of the date of the hearing before Administrative Law Judge Murray.

In her initial decision, Administrative Law Judge Murray found that the ERA's March 15, 1985 filing and subsequent inaction confirmed Boundary's position that the ERA for all intents and purposes had given section 3 approval to the imports under the amended contract terms. She then characterized the issue as whether the FERC has "authority under sections 4 and 5 of the NGA to reject a rate design which simply echoes the terms of an import arrangement approved by the ERA under section 3 of the same statute . . ..* In resolving that issue, Administrative Law Judge Murray found that under the peculiar circumstances, the FERC was constrained to approve Boundary's tariff providing for passthrough of TransCanada's charges on an "as-billed" basis. She found resolution of the jurisdictional issue simplified by those peculiar circumstances, viz., that Boundary is a shell, tailored by the owner-repurchasers with Commission approval, having the sole function of enabling the repurchasers to import and buy gas from TransCanada; the fact that the gas at issue is not mixed with other pipeline supplies in interstate commerce before Boundary resells it to the repurchasers; and evidence submitted at the hearing that rejection by the FERC of the proposed tariff would directly affect the success of the ERAapproved section 3 import authority granted to Boundary, since the repurchasers would not purchase gas from Boundary under the volumetric rate proposed by the FERC staff.

Judge Murray noted that the Secretary's Guidelines to Delegation Order No. 0204-112 unambiguously state that in its regulatory decisions on a gas supply authorized for importation, the FERC "will adopt the terms and conditions attached by the ERA Administrator to the import authorization, thus acting consistently with the determinations made by the Administrator and the policy considerations reflected in the authorization." Judge Murray found that the ERA-approved gas purchase contract

79. Boundary Gas, Inc., 34 FERC 963,099 (1986).

80. Id., mimeo at 18.

81. Id., mimeo at 18-19, quoting 49 Fed. Reg. at 6,689 . 
[VOL. XXV, NO. 1

and the proposed tariff were inseparable because of the "conduit-only" function of Boundary. In view of the uncontradicted evidence that the repurchasers would not buy gas from Boundary under a volumetric rate, she fould the rejection of the proposed new tariff would most likely defeat the ERA-approved import authority.28

At least one FERC Commissioner has acknowledged that the Commission must come to grips with the issue of whether to allow costs related to imports of Canadian gas to be passed through to U.S. customers on an "asbilled" basis, but has stated that it is not likely that this issue will be resolved until the block-billing question ${ }^{83}$ has been resolved. ${ }^{84}$ In turn, he predicted no decision on block-billing until the Commission has first decided what to do with the DOE proposal on old gas pricing, "s though he stated that the Commission will strive to meet the Secretary of Energy's requested deadline of June 1, 1986 for final action on the DOE proposal..$^{86}$

In renoticing the block-billing proposal," the FERC eliminated the previously proposed Block 3, which would have preserved the "as-billed" principle, but clarified that demand charges from upstream domestic pipeline suppliers would continue to be flowed through the demand charge of the purchasing pipeline. ${ }^{83}$ With respect to imported gas, the Commission acknowledged that it had set for hearing in a number of proceedings, the issue of the appropriate rate treatment of two-part rates charged U.S. pipelines by their Canadian suppliers, but stated that such issue "stands separate and apart from the block-billing mechanism". The Commission, therefore, proposed to continue to allow purchasers of imported gas to file to reflect costs on an "as-billed" basis, and to subject such filings to review on a case-by-case basis. ${ }^{\circ}$

The DOE in its comments to the revised block-billing proposal ${ }^{90}$ has criticized the FERC's position and reiterated its position that there should be no regulatory distinction between the treatment of domestic and imported gas supplies. The DOE stated its belief that the two-part rate design utilized in new import arrangements is largely analogous to twopart rates which are accepted in domestic tariffs that recognize the costs in providing transportation over long distances, and that no rationale exists for denying imported gas the same treatment with regard to the "as-billed" passthrough that is available to domestic pipelines. The DOE in its comments has acknowledged that the FERC has "sufficient authority" to

82. Id., mimeo at 20.

83. See infra n. 87; see also text of Part II, supra.

84. See Foster Natural Gas Report, No. 1552 (January 23, 1986) at 14, "Remarks of Commissioner C.M. "Mike" Naeve to a meeting of the Association of Texas Intrastate Natural Gas Pipelines on January 17, 1986, in Houston, Texas". See also, discussion in Order No. 451, infra, at 51 Fed. Reg. 22,210 and 22,211.

85. Notice of Proposed Rulemaking; Ceiling Prices; Old Gas Pricing Structure, Docket No. RM86-3-000, S0 Fed. Reg. 48,540 (November 25, 1985).

86. See supra n. 84.

87. Notice Requesting Supplemental Comments issued October 9, 1985, in Docket No. RM85-1OOO (Part D), 50 Fed. Reg. 42,372 (October 18, 1985).

88. Id. , mimeo at 68.

89. Id., mimeo at 69-70.

90. Supra n. 72 cites these Comments. 
take the appropriate action if it has concerns about the allocation of imported gas costs between demand and commodity charges, but has urged "regulatory restraint in any unnecessary intrusion into private contractual matters", as long as the result of "international contracts freely negotiated between commercial parties" is reasonable and approved by the ERA. ${ }^{91}$

The FERC must come to terms with the "as-billed" issue, and when it does it will be faced with clear indications of policy from the DOE and the unequivocal position of the ERA. However, the longer the FERC delays in addressing the issue, the more chance exists that the controversy may be reduced by actions such as that taken by the NEB on December 19, 1985 . On that date, the NEB approved elimination of producer fixed costs from the demand charge component in contracts between TransCanada Pipelines Ltd. and two U.S. importers, ANR Pipeline Company and Natural Gas PipeLine Company for purchases at Emerson, Manitoba. ${ }^{92}$ One of the major arguments against "as-billed" passthrough for Canadian gas costs has focused on the difference between costs that the NEB and the FERC allow to be recovered in demand charges. To the extent that NEB policy concerning allocation of costs between the demand and commodity components begins to resemble that of the FERC, the FERC may find it increasingly difficult to justify denying imported gas the same treatment which regard to "as-billed" passthrough that is available to domestic pipelines.

The resolution of this issue will affect the relative marketability of Canadian gas in U.S. markets, because it will determine the Canadian gas cost component of the commodity rate for pipelines purchasing Canadian gas.

\section{PROJECTS TO SERVE NORTHEAST U.S. MARKETS}

In the past several years, a number of natural gas pipeline companies have filed applications with the FERC to construct and operate facilities incidental to the transportation of imported Canadian gas to the Northeast United States. Several applications have been filed with the NEB in Canada to export the natural gas to serve these Northeast markets. As market, supply and regulatory conditions have changed, the various proposals are likewise changing, and new or amended applications before the FERC are commonplace. ${ }^{.3}$

\section{A. BOUNDARY GAS}

The first proposal filed with the FERC was the application by Boundary Gas, Inc. (Boundary), a consortium of thirteen distributing companies plus National Fuel Gas Supply Corporation: (i) to import natural gas from Canada at a point near Niagara Falls for resale to the repurchasers at the border; and (ii) proposals by Tennessee Gas Pipeline Company, a Division of Tenneco Inc. (Tennessee), (a) to import certain other volumes of natural

91. Id.

92. See Foster Natural Gas Report, No. 1549 (January 2, 1986) at 30.

93. This paper discusses the major applications and is not intended to be all inclusive. 
gas from Canada at the same entry point, (b) to construct certain pipeline looping and compression facilities, and (c) to transport those volumes as well as the Boundary volumes to markets in the Northeast U.S. ${ }^{* 4}$ Boundary proposed to purchase the natural gas from TransCanada Pipelines Ltd. (TransCanada) pursuant to a natural gas purchase contract.

\section{B. NIPS}

The next project, Niagara Interstate Pipeline System (NIPS), has evolved through various filings in a number of dockets. ${ }^{95}$ Basically, each proposal and amendment contemplated importing Canadian natural gas at Niagara Falls: (i) for use as system supply by Transcontinental Gas Pipe Line Corporation (Transco) and Texas Eastern Transmission Corporation (Texas Eastern); (ii) as a year-round supply sold incrementally to various customers of Algonquin Gas Transmission Company (Algonquin); and (iii) to provide a winter gas supply which would be sold incrementally to various customers of Transco and Algonquin. The initial NIPS proposal filed by Transco provided for 158 miles of pipeline extending from the United States-Canadian border near Niagara Falls to the Leidy Storage Field near Tamarack, Pennsylvania. This NIPS proposal has been changed several times, but it would serve no useful purpose to describe these changes.

\section{CANAM/UNITED STATES ROUTE}

During the first half of 1984, Ohio Interstate Pipeline Company (Ohio Interstate), ANR Pipeline Company (ANR) and Northern Border Pipeline Company (Northern Border) filed applications with the FERC proposing to construct and operate new and/or expanded facilities for the purpose of transporting imported Canadian natural gas for certain shippers. ${ }^{96}$ The combined facilities were called by their sponsors the "United States Route", which was presented as an alternative to the NIPS application. Very briefly, the United States Route proposal was premised on imported Canadian volumes being delivered to Northern Border at Monchy, Saskatchewan. Northern Border would transport the gas through existing and proposed facilities to a point of interconnection with ANR at Sandwich, Illinois. ANR proposed to transport the volumes, received from Northern Border, through its system and to redeliver those volumes to Ohio Interstate at a proposed interconnection in Defiance County, Ohio. Ohio Interstate proposed to transport the imported volumes received from ANR through new pipeline facilities extending from Defiance County, Ohio to proposed interconnections with Tennessee, Transco and Texas Eastern Transmission Corporation (TETCO), in Pennsylvania. This proposal was abandoned by the sponsors in December, 1985.

94. Boundary Gas, Inc., Docket No. CP81-107-000, et al.

95. Niagara Interstate Pipeline System, Docket No. CP83-170-000, et al.; See Foster Natural Gas Report, No. 1558 (March 6, 1986) at 27.

96. Ohio Interstate Pipeline Company, Docket No. CP84-318-000, et al. 


\section{NATURAL'S "TEXAS CROSSOVER"}

Natural Gas Pipeline Company of America (Natural) filed an application proposing to construct and operate new and/or expanded facilities for the purpose of transporting imported Canadian gas as well as for the movement of Natural's system supply between its Amarillo and Gulf Coast pipelines."

Natural requested authorization to construct and operate approximately 185 miles of 24 inch pipeline and certain compressor facilities to be known as the "Texas Crossover". These facilities would extend from Montegue County, Texas to Cass County, Texas, connecting Natural's Amarillo and Gulf Coast lines. Natural proposed to receive imported Canadian volumes from Northern Border at Ventura, Iowa and transport such gas volumes through Natural's Amarillo system, an enlarged Texas Crossover segment and the Gulf Coast system. Gas would be delivered to the shipper at existing interconnections with Natural in the Gulf Coast areas of Texas and Louisiana.

\section{E. ERIE/TRANSYLVANIA}

Recently, affiliates of Transco Energy Co. and Coastal Corporation's ANR Pipeline Company filed applications with the FERC to construct two new pipelines capable of delivering an additional $545 \mathrm{MMcf} / \mathrm{d}$ into the Northeastern United States by late $1987 .^{98}$ These affiliates propose to construct the Erie Pipeline System, which will extend 379 miles from an interconnection with existing ANR facilities in Defiance County, Ohio eastward through northern Ohio and western Pennsylvania to an interconnection in Clinton County, Pennsylvania with proposed facilities of Transylvania Gas Pipeline Co., Inc., another Transco subsidiary. The Erie pipeline, to be constructed and operated by ANR at an estimated initial cost of $\$ 313$ million, would transport up to $425 \mathrm{MMcf} / \mathrm{d}$ of gas originating from both Canada and the Gulf Coast region.

The Transylvania pipeline, consisting of an 81-mile expansion of Transcontinental Gas Pipe Line Corp's Leidy Line system to the New York and New Jersey market area, is projected to cost $\$ 132$ million and is designed to carry all gas to Northeast markets delivered through the Erie system plus an additional $120 \mathrm{MMcf} / \mathrm{d}$ from nearby storage areas in Pennsylvania. Gas supplies from western Canada would be imported into the U.S. at the Minnesota-Manitoba border for delivery to the Northeast through the Great Lakes Gas Transmission Company, ANR Pipeline Co. and the Erie and Transylvania systems. Gulf Coast area gas supplies also would be transported to the New York/New Jersey market through ANR Pipeline Co. and the Erie and Transylvania systems.

\section{F. OTHER PROPOSALS}

In addition to these filed applications, other plans to transport imported Canadian natural gas are being unveiled. One plan, known as the Iraquois

97. Natural Gas Pipeline Company of America, Docket No. CP84-325-000, et al.

98. Erie Pipeline System, Docket No. CP86-329-000; Transylvania Gas Pipeiline Co., Inc., Docket No. CP86-333-000; See Foster Natural Gas Report, No. 1557 (1986) at 27. 
Gas Transmission System, would consist of a 350 mile line with capacity to move $400,000 \mathrm{Mcf} / \mathrm{d}$ into the New York/Connecticut area. ${ }^{9}$ This plan is sponsored by TransCanada and a number of eastern utilities which also belong to the Boundary group. This system, and the Erie Pipeline System and Transylvania Gas Pipeline Co., Inc., would be constructed at the sponsor's risk under FERC Order No. 436 expedited certificates and supposedly would not compete with the NIPS proposal.

Also, there have been recent discussions between Natural Gas Pipeline Company of America and Northern Natural Gas Company, Division of Enron Corp. concerning a plan to move new Canadian supplies by displacement to the Northeast markets. ${ }^{100} \mathrm{Gas}$ would be delivered through Northern Border Pipeline Company and displaced to the Gulf Coast producing region, where domestic volumes could be sent to the Northeast through the systems of Texas Eastern, Transco and Tennessee. This plan would replace an earlier project which involved only Natural Gas Pipeline Company.

The possibility exists that Northern Border Pipeline Company will file for authority to extend its facilities from Ventura, Iowa to an interconnection with the Panhandle Eastern Pipe Line Company near Chrisman, Illinois. ${ }^{101}$ Such an extension would be designed to serve United States markets, including the Northeast.

\section{G. CANADIAN PROPOSALS}

Several applications also have been filed with the NEB in Canada. Foothills Pipe Lines (Yukon) Ltd. (Foothills) filed an application with the NEB requesting authorization to expand its existing pipeline facilities to allow it to transport all of the natural gas required by the Northeast markets. On December 6, 1984 Foothills joined with Northern Border, ANR Pipeline Company and Ohio Interstate Pipeline Company to cosponsor the CanAm-United States route, which would utilize the Foothills Eastern Leg system. ${ }^{102}$

TransCanada Pipelines Ltd. also has filed an application with the NEB to accommodate the export from Canada of the volumes proposed to be imported by United States purchasers. ${ }^{103}$

In all likelihood, no single project ultimately will receive transportation authorization, but rather several projects will be combined and certificated. The viability of any of these projects may be affected by the extent of widespread transportation as a result of Order No. 436.

\section{CALIFORNIA EOR MARKET}

\section{A. DESCRIPTION OF THE MARKET}

Enhanced oil recovery (EOR) refers to the production enhancement techniques used to recover heavy oil which would otherwise not be

99. Faster Natural Gas Report, No. 1554 (February 6, 1986) at 13-14.

100. Faster Natural Gas Report, No. 1564 (April 17, 1986) at 28-29.

101. Id.

102. "TransCanada Pipelines Limited/Foothills Export Facility" Proceeding.

103. Id. 
recoverable economically by conventional production techniques. Steam is injected into the reservoir to reduce the viscosity of the oil, which allows it to be pumped to the surface more easily.

Substantial heavy oil reserves are found in the San Joaquin Valley in Central California, concentrated in Kern County, where heavy oil production has increased during the last ten years. Heavy oil producers in the San Joaquin Valley have been burning field crude oil, primarily, for the fuel to generate the steam to be injected. However, these producers have decided to switch to natural gas, primarily for environmental reasons, but also because gas-generated steam can be used in cogeneration projects.

Because the steam injection process requires a steady supply of steam to prevent damage to the oil formation, the EOR market requires a firm uninterruptible supply of gas to fuel steam generation. The market has been estimated at approximately 700 to $1,050 \mathrm{MMcf} / \mathrm{d}$ between 1986 and 1991, primarily from four producers: Texaco, Chevron, Mobil and Shell.

\section{B. THE TRANSPORTERS}

Transportation to the EOR market involves an interesting interaction of state and federal regulation. Currently, two distributors - Pacific Gas \& Electric Company (PG\&E) and Southern California Gas Company (So Cal) - serve the entire state of California and are fighting over the EOR markets. In addition, three applications have been filed with the FERC for the construction of new pipelines into Kern County to provide transportation of interstate gas to the EOR market: Mojave, El Dorado and Kern River. ${ }^{104}$

\section{CALIFORNIA TRANSPORTATION PROGRAMS}

On December 20, 1985, the Utilities Commission of the State of California (CPUC) issued an Interim Opinion requiring So Cal, PG\&E and San Diego Gas and Electric Company to file tariffs holding themselves out to provide long-term transportation of customer-owned gas to all customers meeting minimum size requirements. ${ }^{105}$ CPUC adopted a transportation rate applicable to EOR customers based on the cost of service as if provided by an interstate pipeline subject to the jurisdiction of the FERC.

Recognizing the long-term security of supply needed by EOR customers, and indicative of the historic concern over allowing interstate pipelines into California, the CPUC stated: ${ }^{106}$

Thus, transportation may facilitate the service of this important new market by the existing gas distribution system, and forestall uneconomic bypass by an interstate pipeline....

Based on the record, an interstate pipeline cannot be justified except by an abiding faith that this Commission will fail to regulate effectively. The proposed pipeline is not needed to serve the market. The economically efficient solution is to serve the EOR market from existing facilities. But if contracts are signed to support the financing of the pipeline, then it will be built. If the possible EOR contribution is all that is at stake, one could argue that

104. CP85-437-000 et al.

105. Decision 85-12-102, 1.84-04-079, December 20, 1985.

106. Id. at 7,9 . 
[VOL. XXV, NO. 1

we could forego transportation in order to keep the utility monopoly intact. However, an interstate pipeline would have the potential to be extended to serve existing industrial customers, with possibly disastrous consequences for the ability of this Commission to design rates based on local considerations.

In arriving at a rate structure for PG\&E and So Cal to charge to their EOR customers, the CPUC's stated intent is to provide the two utilities with the negotiating flexibility required to meet the needs of their EOR customers and to meet the competition of the interstate pipeline proposals. The CPUC set the rate at 3.0 cents per therm (30 per MMBtu) in 1986, escalated by changes in the utilities' margin in subsequent years, limited to an escalation rate of three to five percent.

In order to provide an incentive to the utilities to negotiate higher rates, shareholders will be allowed to retain $25 \%$ of the annual revenues derived from rates in excess of the escalating 3.0 cents per therm minimum rate. This rate applies to all gas transported to the EOR facilities including gas used for cogeneration. The minimum contract term is five years, and there is no maximum term. ${ }^{107}$

The CPUC's order also encouraged PG\&E to negotiate transportation and exchange arrangements and compensatory rates to provide service for Canadian and California producers wishing to sell gas in the So Cal territory and for PG\&E to obtain gas from the Transwestern system. ${ }^{108}$

Apparently, PG\&E and So Cal working together could serve up to 700 MMcf/d of the EOR market if the producers are willing to make sizeable investments based on the California regulatory scheme rather than an FERC-regulated interstate pipeline.

\section{IMPACT ON CANADIAN SUPPPLIERS}

There are a number of ways that Canadian suppliers may eventually gain access to the EOR market. The Kern River Pipeline ${ }^{199}$ via Northwest Pipeline, estimates availability of $350 \mathrm{MMcf} / \mathrm{d}$ from Canada, and 350 MMcf/d from Overthrust. The El Dorado Pipeline, ${ }^{110}$ via Transwestern or El Paso, indicates up to $600 \mathrm{MMcf} / \mathrm{d}$ availability in Canada. The Mojave Pipeline III $^{11}$ is virtually identical to the El Dorado proposal.

Finally, with open transportation under Order No. 436, there exist a number of other possibilities for moving Canadian gas to EOR markets via other routes through exchange and displacement.

\section{OTHER REGULATORY DEVELOPMENTS}

\section{A. LEGISLATIVE DEREGULATION}

There is a push from certain quarters for price deregulation of old gas and removal of certain restraints on the burning of natural gas. ${ }^{12}$ On the

107. Id. at 25 et seq.

108. Id. at $31 \mathrm{~b}, 32$.

109. $50 \%$ Tenneco, $50 \%$ Williams Gas.

110. $50 \%$ Lear Petroleum, $50 \%$ TransCanada.

111. 331/3\% El Paso, 331/3\% HNG Mojave, 331/3\% Pacific Interstate.

112. Under the Natural Gas Policy Act of 1978 ("NGPA"), certain "old gas" is forever regulated. Generally referred to as "104 gas", the regulated price of this gas ranges from \$.319 to \$2.56. 
first front, the Department of Energy (DOE) has proposed a bill entitled "The Natural Gas Policy Act Amendments of 1986", which would:113

(i) Expand NGPA S311(a)is4 to permit the FERC to authorize any pipeline to transport on a selfimplementing basis "on behalf of any person" (rather than on behalf of intrastate pipelines and local distribution companies only), and require the FERC, upon the request of any person, to direct an interstate pipeline to transport gas if it has capacity;

(ii) Remove NGPA price controls'ts immediately from natural gas sold under contracts executed or renegotiated after March 1, 1986 (if the renegotiated contract provided for decontrol) and remove all NGPA controls effective April 1, 1987. In addition, the Act would remove FERC certificate and abandonment authority over "first sales" of such gas"16 so that it could be sold by producers without such authority.

(iii) Repeal the incremental pricing provisions of the NGPA 117 and the portions of the Fuel Use Act 118 which prohibit the use of natural gas and petroleum as a primary energy source in new electric power plants and new major fuel-burning installations.

It is not clear whether such comprehensive legislation has much chance of adoption in the near future, although, as of the time of writing in July of 1986, there is much activity centered around a "Discussion Draft" being circulated by the House of Representatives Energy and Commerce SubCommittee on Fossil and Synthetic Fuels. ${ }^{119}$ However, there continues to be a push for more limited legislation simply to repeal the Fuel Use Act and incremental pricing. ${ }^{20}$

\section{B. ADMINISTRATIVE DEREGULATION}

On June 6, 1986, the FERC issued Order No. 451, adopting a final rule ${ }^{121}$ that revises the maximum lawful price for natural gas under sections 104 and 106 under the NGPA. The rule also establishes procedures intended to make the price for such gas responsive to actual conditions in the marketplace by eliminating "vintage-based" pricing for all old gas through the establishment of a uniform ceiling price equal to the highest current ceiling price for old gas, which is the post-1974 vintage. ${ }^{12}$ The rule was

113. DOE NEWS, April 10, 1985.

114. 15 U.S.C. $53371(a)$.

115. Id. at $\$ 3331$.

116. Id. at $\$ 3431(\mathrm{a})(1)(\mathrm{B})$.

117. Id. at 53341-3348.

118. 42 U.S.C. 58301 , et seq.

119. "House Staff Looks To Put Finishing Touches on Mandatory-Carriage Bill", Inside FERC, July 14, 1986.

120. S. 1251. April 16, 1986 letter from Senators Johnston, et al., to Senator McClure, Chairman of the Senate Committee on Energy and National Reserves.

121. S1 Fed. Reg. 22,168 (June 18, 1986).

122. "Old gas" or "flowing old" gas is generally natural gas that was "committed or dedicated" to interstate commerce (i.e., by contract and/or certificate issued by the FERC or its predecessor) on the day before enactment of the NGPA (November 8, 1978), as well as intrastate flowing gas subject to the price ceilings "maximum lawful prices" for intrastate rollover contracts under Section 106(b). Sections 104(b)(2) and 106(c) permit the Commission by rule or order to prescribe a price higher than the otherwise applicable NGPA maximum lawful price, provided it is "just and reasonable" within the meaning of the Natural Gas Act. "New" gas is priced under NGPA sections 102, 103, 105 and 108. Most new gas was deregulated at the wellhead by the NGPA effective January 1, 1985 and July 1, 1987. "Vintage" or "vintaging" generally refers to pricing of gas according to various categories based on when the well was spudded. 
issued in response to a November 18, 1985 Department of Energy (DOE) Notice of Proposed Rulemaking (NOPR) under section 403 of the Department of Energy Organization Act ${ }^{12}$ for action by the FERC.

Under the rule promulgated by the FERC, ${ }^{124}$ producers may collect a new alternative maximum lawful price, but only to the extent permitted by their contracts. However, indefinite price escalator clauses ${ }^{12}$ in existing contracts provide the necessary authority. Also, producers must follow the prescribed "good faith negotiation" procedure.

Under the "good faith negotiation" procedure, if the producer seeks renegotiation to increase the price of old gas, the purchaser may seek renegotiation to decrease the price of any gas under any existing contract with the purchaser that includes the sale of any old gas. If the renegotiation efforts are unsuccessful and the producer finds another buyer for the gas, the producer is granted "abandonment" and blanket certificate authority to sell the gas elsewhere in interstate commerce for resale, and the former purchaser/pipeline must transport the gas for the producer. ${ }^{126}$ If the purchaser rejects a price nominated by the producer, the purchaser may terminate its purchases of all or part of the gas named in its request.

Existing firm sales customers of the pipeline are given a right of first refusal if the pipeline is not an open-access transporter under Order 436, supra. ${ }^{127}$

Extensive rehearing requests have been filed by all segments of the industry and other affected parties. ${ }^{123}$ Pipelines, distributors and consumer groups are challenging the FERC's authority to prescribe higher just and reasonable prices on the basis of replacement cost and to require mandatory transportation of abandoned gas by pipelines. The Order is also challenged as to its impact on the consumer. ${ }^{120}$ In addition, one pipeline already has sought extraordinary relief from the U.S. Court of Appeals, asking the Court to vacate Order 451 on the basis that the FERC has exceeded its jurisdiction. ${ }^{130}$

\section{BLANKET IMPORT AUTHORIZATIONS}

Canadian participation in the U.S. spot gas market has been facilitated by the vehicle of blanket import authorizations issued by the Economic Regulatory Administration (ERA) of the Department of Energy. ${ }^{131}$ Participation in these import arrangements seems to be fairly broadly-based,

123. 42 U.S.C. 57173 (1982).

124. 18 C.F.R. Part 270, S270.201, part 271, \$271.402, \$271.602, S1 Fed. Reg. 22,218-22,221 (1986).

125. The most common form of indefinite price escalator clause ties the price to the highest just and reasonable price or highest area or national rate or some variation thereof.

126. 18 C.F.R. Part 157, S157.301, Part 270, S270.201(h), St Fed. Reg. 22,219-22,220 (1986).

127. Id. at $\$ 270.201(\mathrm{~g})$.

128. A helpful summary of some 60 applications for rehearing is given in Foster Report No. 1576, July 10, 1986 at $1-10 B$.

129. See, for example, Request of Northern Natural Gas Company, Division of Enron Corp. for Rehearing, Filed July 7, 1986, and Request of The American Gas Association for Rehearing of Order No. 451, filed July 3, 1986, Docket No. RM86-3-000.

130. In Re: K-N Energy, Inc., U.S.C.A., 8th Cir., No. 86-1806, filed July 9, 1986.

131. Foster Natural Gas Report, No. 1561 at 29. 
involving Canadian producers and marketers, as well as TransCanada, U.S. pipelines and their affiliates and U.S. marketers. ${ }^{132}$

The decisions of the ERA reflect a policy of favoring competition from Canadian suppliers. Such policy, of course, fits with the present and future Canadian policies, as well as aggressive participation by Canadian interests, such as the recent netback pricing scheme proposed by Western Gas Marketing Ltd., a TransCanada affiliate.

\section{LIMITED TERM ABANDONMENTS}

Under the Natural Gas Act and NGPA, certain categories of gas remain "dedicated" to interstate commerce and to specific pipelines, i.e., the gas cannot be sold elsewhere without FERC abandonment and recertification authority. Recently, the FERC has adopted a policy of freeing lower-priced packages of such gas not currently needed or desired by the particular pipeline purchasers, for sale by producers to other markets. The first step was the Felmont Oil case, ${ }^{133}$ in which the FERC approved partial limited term abandonment (LTA) of gas dedicated to Transco for a period of three years. The abandonment authority extends to volumes not nominated by Transco, and requires that Transco's customers have first rights to bid for remaining volumes.

In a further step, the FERC on March 5, 1986, granted LTA authority to Pennzoil Producing Co. and Pennzoil Gas Marketing Co. to abandon sales of system gas dedicated to United Gas Pipeline Co. and to sell such gas to other purchasers. ${ }^{134}$ The gas was released by United, subject to recall as part of a take-or-pay settlement.

Previously, some fifty (50) applications for LTA's were granted in late 1985, covering higher-priced gas, and on March 28 and 31, 1986, the FERC. issued orders extending certain LTA's, or in some cases granting new ones, for a period of one year through March 31, 1987. ${ }^{135}$

\section{E. STATE CARRIAGE PROGRAMS}

Finally, a number of states have developed or are in the process of developing programs which require or encourage carriage. The long-term program in California has been followed by a program requiring the California utilities to file short term transportation tariffs. ${ }^{136}$ In addition, a November, 1985 telephone survey conducted by the Interstate Natural Gas Association of America revealed that states representing about $80 \%$ of the interstate gas market either already have transportation programs in place or soon will. ${ }^{137}$

132. E.g., Texas Eastern Gas Trading Co. (86-19-NG); Pro-Gas U.S.A. (86-20-NG); IGI Resources, Inc. (86-21-NG); Gas Ventures, Inc. (86-04-NG); Agar Resources, Inc. (86-07NG); Midwestern Gas Transmission Co. (86-03-NG); El Paso Gas Marketing Co. (85-32NG); PGC Marketing, Inc. (86-01-NG); ICG Energy Marketing, Inc. (86-23-NG); Cariyle Energy, Inc. (86-24-NG).

133. FERC Opinion No. 245, issued December 9, 1985, Docket No. CI84-10 et al.

134. Docket Nos. CI86-54-000 and CI86-57-000.

135. Columbia Gas Transmission Corp., et al., Docket No. CP83-452-047; Marathon Oil Co., et al., Docket No. CI85-651-001.

136. Decision No. 86-03-057, March 19, 1986, 1.84-04-079.

137. Inside F.E.R.C., December 23, 1985 at 9. 
[VOL. XXV, NO. 1

\section{F. COMMENT}

The above developments foster the freeing up of supply and markets, with the result that there are increased opportunities for the marketing of Canadian gas, but also increased competition from U.S. supplies.

\section{APPENDIX "A" \\ JURISDICTIONAL DIVISION OF AUTHORITY BETWEEN THE FEDERAL ENERGY REGULATORY COMMISSION AND THE ECONOMIC REGULATORY AUTHORITY}

In 1977, the United States Congress passed the Department of Energy Organization Act (the "Act"). ${ }^{138}$ Under the Act, the Secretary of Energy (Secretary) was given responsibility for implementing section 3 of the Natural Gas Act (NGA), which relates to natural gas imports and exports. The Act abolished the Federal Power Commission (FPC), which was formerly vested with jurisdiction over imports and exports under section 3 of the NGA, and established the Federal Energy Regulatory Commission (FERC). The FERC was vested with authority to exercise jurisdiction under sections $1,4,5,6$ and 7 of the NGA, and to regulate certain aspects of the domestic natural gas industry within the United States, including regulation of wellhead prices and transportation rates for gas transported in interstate commerce.

The Act empowered the Secretary to delegate authority under section 3 of the NGA to others within the Department of Energy. The Secretary has issued orders delegating section 3 authority to the Economic Regulatory Administration (ERA) and to the FERC. By Delegation Order 0204-4, issued in November, 1977 but effective retroactively to October 1, 1977, ${ }^{139}$ the Secretary delegated to the Administrator of the ERA the authority to adopt rules, issue orders, licences and other allocations, collect fees and take such other action as may be necessary and appropriate to administer the exportation and importation of natural gas pursuant to the provisions of section 3 of the NGA and Executive Order 10485, except with respect to those pending cases assigned by rule to the FERC. However, the Secretary delegated to the FERC the power recognized under section 3 of the NGA to approve or disapprove the site, construction and operation of particular facilities, as well as the place of entry for imports, in Delegation Order No. 0204-06. 100

Subsequent delegations by the Secretary to the ERA and FERC anticipated that the ERA might impose conditions on permits issued under section 3 of the NGA which would overlap with areas - such as the pricing structure of natural gas - over which the FERC normally would have jurisdiction. ${ }^{141}$ Delegation Order No. 0204-25'12 to the ERA instructed the

138. Pub. L. No. 95-91, 91 Stat. 565,42 U.S.C. 57101 et seq.

139. 42 Fed. Reg. 60,726 (Appendix) (Nov. 29, 1977).

140. Id.

141. See West Virginia Public Services Com'n v. U.S. Department of Energy, 681 F.2d 847 at 858 (D.C. Cir. 1982).

142. 42 Fed. Reg. 47,769 (October 17, 1978). 
Administrator to attach such terms or conditions to import or export authorizations as he should determine to be necessary to make the import or export not inconsistent with the public interest, and stated that the FERC should include such terms and conditions in any order it issued which authorized the import or export pursuant to Delegation Order No. 0204-26.10 Delegation Order No. 0204-26 expressly confirmed that the FERC was to perform "all functions under sections 4,5 , and 7 " of the NGA, even though arising in connection with a section 3 application. While the language of Delegation Order No. 0204-25 generally required the FERC to issue orders consistent with the ERA-imposed terms, the language of Delegation Order No. 0204-26 created power in the FERC to effectively veto the ERA's conditional grant of an import or export authorization when "inconsistent with provisions of the Natural Gas Act which the F.E.R.C. has been delegated authority to administer" by Order No. 0204-26 itself or which were otherwise vested in the FERC.

This lack of clarity with respect to division of authority under section 3 of the NGA was carried forward by Delegation Orders Nos. 0204-54 and 0204-55, issued September 27, 1979.14 The latest delegation by the Secretary to the ERA and FERC occurred in February, 1984, when the Secretary issued "New Policy Guidelines and Delegation Orders from Secretary of Energy to Economic Regulatory Administration and Federal Energy Regulatory Commission Relating to Regulation of Imported Natural Gas" ("New Policy Guidelines") and Delegation Orders Nos. 0204-110, -111, and -112.145

In the new policy guidelines, the Secretary acknowledged that the lines of jurisdiction and authority had "not been entirely clear" and stated that the objective in the issuance of new Delegation Orders 0204-110 through -112 was to achieve efficiencies under the unavoidable two-part regulatory process through clarification of the ERA and FERC gas import responsibilities and through streamlining some aspects of the process.

As described by the Seeretary in the text of the new policy guidelines, under the new delegation orders, all gas imports - including gas transported through the ANGTS prebuild - will be authorized by the Administrator of the ERA. Delegation Order No. 0204-8, which gave this authority for ANGTS to the FERC, was rescinded by Delegation Order No. 0204-110. The Administrator of the ERA is to exercise this authority over imports consistent with the new policy guidelines and Delegation Order No. 0204-111..$^{146}$

The FERC, under the revised delegation orders, maintains its responsibility for exercising sections 4,5 , and 7 authority under the NGA over gas authorized for import by the Administrator. Gas authorized for importation is "subject to the FERC's review of issues pertaining to siting, construction, and operation of pipeline facilities, and to the rates proposed to be charged for the interstate transportation and sale of the gas". ${ }^{147}$ In its

143. Id.

144. 44 Fed. Reg. 56,735 (Oct. 2, 1979).

145. 49 Fed. Reg. 6,684-6,691 (February 22, 1984).

146. Id.

147. Id. 
[VOL. XXV, NO. 1

regulatory decisions on a gas supply authorized for importation, the FERC is directed by the new policy guidelines to "adopt the terms and conditions attached by the ERA Administrator to the import authorization, thus acting consistently with the determinations made by the Administrator and the policy considerations reflected in the authorization". ${ }^{149}$

While authority delegated to the ERA by Delegation Order No. $0204-$ 111 does not include authority to approve the construction and operation of particular facilities, the Administrator is authorized to disapprove the site of such facilities, or the place of entry for imports or exit for exports with respect to construction of new domestic facilities. The Administrator may disapprove on the basis of considerations, including in the case of imports, the competitiveness of the import; the need for the natural gas; and security of supply, and including in the case of exports, considerations of the domestic need for the gas to be exported and such other matters as the Administrator finds to be appropriate in the circumstances of a particular case.

The only United States Court of Appeals that has construed the new policy guidelines and delegation orders has concluded with respect to the jurisdiction of the FERC (Commission) that: ${ }^{149}$
In sum, the Commission is statutorily obligated under sections 4 and 5 of the [NGA] to declare unlawful rates it finds unjust and unreasonable. Pursuant to the section 3 power delegated to it by the Secretary, the Commission is empowered to exercise its sections 4 and 5 powers over imported gas. The only limit placed upon this authority is that the Commission cannot, consistent with the Delegation Orders, take actions inconsistent with the terms, conditions, or policy considerations reflected in the ERA's section 3 import authorization.

However, confusion over the respective authority of the ERA and FERC under section 3 of the NGA has survived the issuance of the new policy guidelines and Delegation Orders Nos. 0204-110 through -112. The issue merely has been rephrased in terms of what FERC actions are inconsistent with the terms, conditions, or policy considerations reflected in the ERA's import authorization.

The two major issues which have arisen in this context are the issue of passthrough of Canadian gas costs on an "as-billed" basis to U.S. customers of importing pipelines, and the issue of whether the FERC exceeded its authority under section 3 of the NGA to regulate importers of natural gas through the issuance of FERC Order No. 380, 130 which eliminated variable costs from certain natural gas pipeline minimum commodity bill provisions. The "as-billed" issue is discussed in Section V of this paper.

On appeal of FERC Order No. 380, one petitioner, Great Lakes Transmission Company (Great Lakes), contended that Order No. 380 was inconsistent with its ERA authorization approving its import of Canadian natural gas from its sole supplier, TransCanada Pipelines Ltd. (TransCanada), under a contract containing take-or-pay provisions. Great Lakes argued that Order No. 380 was inconsistent with the approved take-or-pay

148. Id.

149. Wisconsin Gas Co. v. FERC, supra n. 67 at $1155-56$.

150. Order No. 380, supra n. 36, Order No. 380-A, 28 FERC 961,175; Order No. 380-C, 29 FERC 961,077; and Order No. 380-D, 29 FERC 961,332 (1984). 
clauses, because without variable cost recovery through minimum bills, Great Lakes would be unable to recoup any take-or-pay liability from its partial requirements customers. The Court of Appeals in Wisconsin Gas Co. v. FERC rejected Great Lakes' argument, stating that the fact that Order No. 380 might render contractual provisions more burdensome does not mean that the Order was inconsistent with the terms of the import authorization: ${ }^{131}$

\begin{abstract}
Any action taken by the Commission pursuant to its delegated authority under section 3 is bound to have an impact upon the pipeline selling imported gas, which, in turn, will have an impact upon the pipeline's relationship with its foreign supplier. For the Commission's power under section 3 to have any meaning, however, it must extend to actions such as those taken here, which may indirectly affect the import authorization. Here, the impact upon the authorization is trivial; the Commission's action in no way intrudes upon the responsibilities delegated to the ERA. As such, the Commission's decision cannot be deemed inconsistent with the terms or conditions of the authorization, or with any policy considerations underlying the authorization. We therefore hold that by eliminating the minimum bill in Great Lakes' tariff, the Commission has not exceeded its authority to regulate importers of natural gas.
\end{abstract}

The Wisconsin Gas Co. opinion, which is the only judicial precedent construing the division of section 3 jurisdiction between the FERC and ERA created by the new policy guidelines and the latest delegation orders, provides minimal guidance with respect to the issue. However, a body of case law is beginning to develop at the agency level with respect to the "asbilled" issue. 